\title{
UPAYA PENGENTASAN KEMISKINAN PADA PETANI MENGGUNAKAN MODEL TINDAKAN KOLEKTIF KELEMBAGAAN PERTANIAN
}

\author{
Bondan Satriawan dan Henny Oktavianti \\ Fakultas Ekonomi Universitas Trunojoyo Madura \\ Jalan Raya Telang Po.Box 2 Kamal Bangkalan Madura. Telepon (031) 3013483 \\ E-mail: bs_enduro1978@yahoo.com
}

Diterima 23 September 2011 / Disetujui 18 Mei 2012

\begin{abstract}
The objective of this study is to find way to reduce poverty rate of farmer by looking for the most suitable farm institutions that could be applied nationally. By doing so, this study analyzes, first, poverty condition of farmer through social-cultural approach in order to find the root causes of the farmer poverty. Secondly, this study will analyze current farm institutions. Finally, this study will synthesize the findings and proceed with alternative policies that are based on collective actions to overcome the poverty problem for the farmer. ZOPP (Zielorientierte Projektplanung-Objective Oriented Project Planning) and collective action model are used as the main method of analyze. This study finds that there are eleven root causes of farmer poverty. Furthermore, this study suggest the existence of: market creation, activating and assisting KUT (Farmer Business Union) as well as Gapoktan (Farmer Club), and providing a pilot field for farming for every village.
\end{abstract}

Keywords: poverty reduction, collective action, farmer groups, agricultural institutions

\begin{abstract}
Abstrak: Studi ini bertujuan untuk mencari cara mengurangi tingkat kemiskinan pada petani melalui penciptaan institusi pertanian yang paling sesuai bagi petani dan bisa diaplikasikan secara nasional. Dalam rangka mencapai tujuannya, pertama, dilakukan analisis kemiskinan petani melalui pendekatan sosio-kultural untuk mengidentifikasi akar kemiskinan pada petani. Kedua, dilakukan analisis terhadap institusi pertanian yang ada. Terakhir, dilakukan sintesa temuan-temuan yang dilanjutkan dengan identifikasi kebijakan alternatif berdasarkan tindakan kolektif dalam rangka memecahkan masalah kemiskinan pada petani. ZOPP (Zielorientierte Projektplanung-Objective Oriented Project Planning) dan model tindakan kolektif digunakan sebagai metode analisis utama dalam studi ini. Studi ini menemukan ada sebelas akar penyebeb kemiskinan pada petani. Studi ini juga menyarankan adanya: penciptaan pasar, pembentukan dan pengaktifan KUT (Kelompok Usaha Tani) serta Gapoktan, dan penyediaan lahan percontohan bagi kelompok tani disetiap desa.
\end{abstract}

Kata kunci: pengurangan kemiskinan, tindakan kolektif, kelompok tani, institusi pertanian

\section{PENDAHULUAN}

Kemiskinan merupakan isu yang akan tetap relevan untuk dibahas karena telah menjadi agenda penting, baik di Indonesia maupun di dunia internasional. Secara konseptual kemiskinan diposisikan sebagai isu ekonomi dan isu sosial (Yustika, 2007). Pada tahun 2002-2007, terdapat indikasi kuat bahwasanya meskipun terdapat kecenderungan positif dalam penanggulangan kemiskinan, tetapi ternyata implikasinya belum seperti yang diharapkan (Kuncoro, 2008). Saat ini kemiskinan di Indonesia masih cukup tinggi mencapai 32,53 juta penduduk. 16,68 persen di antara penduduk miskin tersebut berada di provinsi Jawa Timur - yang dijadikan studi kasus dalam penelitian ini. 
Penduduk Indonesia sebagian besar menggantungkan penghidupannya di sektor pertanian, yaitu sebesar 41,18 persen dari total jumlah penduduk Indonesia yang bekerja (BPS, 2009). Demikian pula dengan Jawa Timur yang menjadi lokasi penelitian dalam penelitian ini. Dari jumlah penduduk Jawa Timur yang bekerja, yaitu sebanyak 19.305.000 orang, 42,9 persen bekerja di sektor pertanian (BPS Jatim, 2009). Hal ini menunjukkan bahwa jumlah tenaga kerja yang terserap didominasi oleh sektor pertanian.

Sektor pertanian di Indonesia sebagian besar dibangun oleh petani. Sehingga, kesejahteraan petani harus menjadi perhatian karena pertanian merupakan sektor pendukung ketahanan pangan nasional. Strategi penanggulangan kemiskinan di Indonesia didasarkan pada argumentasi bahwa dengan pertumbuhan ekonomi yang tinggi, kemiskinan akan dapat berkurang melalui mekanisme efek tetesan ke bawah (trickle down effect), namun program ini belum mencapai hasil yang diharapkan (Astuti dan Musiyam, 2009). Banyak faktor yang mempengaruhi masih tingginya angka kemiskinan, terutama pada petani. Faktor kultur dan struktural kerap kali dilihat sebagai elemen penting yang menentukan tingkat kemakmuran dan kesejahteraan masyarakat (Hasibuan, 1993). Salah satu hal yang perlu dianalisis adalah pola kehidupan petani. Pola tersebut sangat dipengaruhi oleh faktor kultur dan struktural yang dapat menentukan tingkat kemakmuran dan kesejahteraan petani. Faktor kultural dan struktural ini sering digunakan sebagai acuan modal sosial (social capital) untuk melihat suatu permasalahan didasarkan pada apa yang dimiliki suatu komunitas. Menurut Fukuyama (1995) modal sosial adalah kapabilitas yang muncul dari kepercayaan umum di dalam sebuah masyarakat atau di bagian-bagian tertentu darinya. Modal sosial merujuk pada hubungan kepercayaan, kebersamaan dan pertukaran, aturan dan norma bersama, keterkaitan, dan jaringan di dalam masyarakat memungkinkan setiap anggota masyarakat melakukan tindakan kolektif (collective action) dan mengamankan sumberdaya penting yang lain. Menurut DiGrego- rio et. al. (2004) satu individu masyarakat secara alami akan cenderung memilih melakukan aksi bersama dengan individu lain ketika mereka merasa ada kesamaan dalam hal tujuan yang ingin dicapai dan ketika merasa ada ketidakpastian serta resiko yang dihadapi jika bergerak sendirian. Dengan demikian, transformasi modal sosial ke dalam tindakan kolektif menjadi bermanfaat sebagai faktor penting untuk mempengaruhi dan menentukan bentuk keputusan dasar, termasuk juga pengaturan kelembagaan pertanian yang akan menjadi titik tekan dalam penelitian ini.

Studi ini mempunyai beberapa tujuan, antara lain: pertama, menganalisis berbagai penyebab kemiskinan pada petani, sehingga melalui analisis pertama tersebut akan dapat diketahui mengapa petani -sebagai salah satu aktor penyedia kebutuhan pangan- masih hidup di bawah garis kemiskinan. Berdasarkan hasil observasi tersebut, maka dapat melangkah ke tahap selanjutnya dengan mengerucutkan inti permasalahan dan merekomendasikan sebuah alternatif kebijakan berbasis tindakan kolektif (collective action). Kedua, melalui studi ini akan diketahui bagaimana sistem kelembagaan pertanian yang berlangsung selama ini. Output yang akan dicapai dalam analisis kedua ini adalah sebagai upaya perbaikan kelembagaan pertanian atau rekomendasi restrukturisasi kelembagaan pertanian (skema kelembagaan pertanian yang tepat). Pendekatan kelembagaan diperlukan sebagai pondasi kelembagaan ekonomi yang mapan untuk menyediakan pembuat kebijakan serta mendesain kesepakatan kelembagaan bagi pertumbuhan dan pembangunan (Yustika, 2006).

Secara lebih spesifik, pertanyaan yang ingin dijawab dalam studi ini adalah: apakah penyebab kemiskinan pada petani?; bagaimana bentuk dan pengaruh tindakan kolektif (collective action) dalam lingkaran kemiskinan pada petani?; program-program apa saja yang diperlukan dalam rangka mengurangi cakupan kemiskinan dan tingkat kemiskinan pada petani?; serta kebijakan-kebijakan apa saja yang kiranya paling diperlukan dalam rangka mengurangi cakupan dan tingkat kemiskinan pada petani? 


\section{METODE PENELITIAN}

\section{Metode Analisis}

Penelitian ini menggunakan metode analisis ZOPP (Zielorientierte Projektplanung) atau metode Perencanaan Proyek yang Berorientasi Tujuan. ZOPP dikembangkan sebagai metode bagi perencanaan proyek, tetapi dalam perkembangannya di Indonesia, sejak tahun 1988 ZOPP juga dikembangkan dalam proses perencanaan pembangunan daerah.

Inti dari metode ZOPP adalah Matrik Perencanaan Program. Matrik tersebut akan memberikan informasi secara ringkas, antara lain mengenai: mengapa program tersebut perlu dibuat, apa yang ingin dihasilkan oleh programprogram tersebut, bagaimana program tersebut akan bekerja untuk mencapai hasil-hasil yang diinginkan tersebut, faktor-faktor lingkungan mana saja yang perlu diawasi demi keberhasilan program, bagaimana keberhasilan suatu program dapat dinilai secara obyektif, serta dari mana data-data yang diperoleh untuk menghasilkan suatu program secara obyektif (Brantakusumah, 2004).

Penggunakan metode ZOPP menyangkut beberapa langkah analisis yang dilakukan secara bertahap dalam penelitian ini, antara lain: participation analysis (analisis partisipatif), problem analysis (analisis masalah), objectives analysis (analisis tujuan), discussion of alternatives (analisis alternatif dan penentuan prioritas), dan protect planning matrix (yang mencakup 4 tahap).

\section{Analisis Partisipatif}

Langkah-langkah yang dilakukan dalam analisis partisipatif antara lain: (1) Identifikasi namanama kelompok dan lembaga di pandang berkepentingan, dan memiliki posisi yang atau dapat dipengaruhi dalam masalah kemiskinan petani. (2) Mendeskripsikan unsur-unsur kepentingan, harapan, kekhawatiran, potensi, dan kelemahan atau hambatan yang dialami. (3) Melakukan analisis terhadap unsur-unsur kepentingan/harapan, kekhawatiran, potensi, dan kelemahan serta implikasi yang mungkin akan muncul dari setiap kelompok masyarakat terse- but. (4) Analisis keterhubungan antarkelompok berkenaan dengan unsur yang ada, sehingga dapat diketahui ada-tidaknya benturan kepentingan (konflik) antarkelompok.

\section{Analisis Masalah}

Langkah-langkah analisis masalah dibuat menggunakan teknik diskusi secara brainstorming. Adapun bentuk langkah-langkah tersebut adalah: (1) Merumuskan masalah utama yaitu kemiskinan petani dan selanjutnya merumuskan berbagai macam masalah penyebab kemiskinan petani, (2) Membuat pohon masalah, dan (3) Membuat matrik masalah dengan melakukan analisis keterhubungan antarmasalah.

\section{Analisis Tujuan}

Analisis tujuan merupakan teknik meneliti tujuan-tujuan yang diharapkan dapat dicapai sebagai akibat dari pemecahan masalah yang telah disebutkan dalam analisis masalah. Sehingga pada tahap ini akan diperoleh pohon tujuan (objectives tree). Langkah-langkah analisis tujuan didasarkan pada pohon masalah dan matrik masalah.

\section{Analisis Alternatif dan Penentuan Prioritas}

Analisis alternatif dan prioritas dimaksudkan untuk mendapatkan program-program yang sifatnya prioritas berdasarkan penilaian terhadap seluru program yang ada. Analisis ini menggunakan kriteria atau pembobotan tertentu atas masing-masing program. Penganalisisan pada tahap ini didasarkan pada hasil analisis tujuan. Selanjutnya memasukkan program-program hasil analisis ke dalam matrik pemilihan program.

Selanjutnya berdasarkan matrik pemilihan program tersebut akan diperoleh program-program yang diprioritaskan. Apabila telah diperoleh daftar program yang dijadikan prioritas, perlu dilakukan pengujian kedua untuk menegaskan program mana yang akan dijadikan program utama dan harus segera diwujudkan. Uji kedua ini dilakukan berdasarkan penilaian kriteria yang telah ditentukan. Proses uji kedua dilakukan menggunakan alat analisis alternatif pemilihan pendekatan program. Sehingga pe- 
neliti harus membuat matrik pemilihan pendekatan program.

\section{Matrik Perencanaan Proyek (Project planning matrix/PPM)}

Matrik perencanaan proyek digunakan untuk menggambarkan ringkasan rancangan program yang telah dibuat dalam bentuk matrik dengan memperhatikan asumsi-asumsi, sumber pembuktian serta indikator untuk setiap tujuan yang ingin dicapai. Matrik perencanaan proyek atau juga dapat disebut sebagai kerangka kerja logis.

Untuk mengisi matrik di atas, ada 4 (empat) tahapan, sebagai berikut:

(1) Tahap 1: Pengisian lajur 1 (purpose). Kolom lajur 1 memberikan rangkuman deskriptif tentang tujuan progam dan upaya pencapaian tujuan. (2) Tahap 2: Pengisian lajur 4 (assumptions) Maksud penetapan asumsi-asumsi adalah untuk menilai tingkat resiko pencapaian tujuan dari pelaksanaan kegiatan serta mengurangi resiko yang masih ada dalam peaksanaan program. Penetapan asumsi-asumsi penting tersebut dilakukan dengan cara menggambarkan skema hubungan antara tujuan dan asumsi. (3) Tahap 3: Pengisian lajur 2 (objective indicators). Pada tahap ketiga adalah merumuskan dan menetapkan indikator-indikator untuk tujuan program, sasaran program, hasil-hasil kerja dan setiap asumsi. (4) Tahap 4: Pengisian lajur 3 (sumber pembuktian).

Yang dimaksud dengan sumber pembuktian pada lajur 3 adalah sumber data yang diperlukan untuk mengukur tingkat pencapaian target yang tercantum pada indikator.

\section{Teknik Pengumpulan Data}

Penggunakan metode ZOPP yang bersifat partisipatif, maka perlu melibatkan masyarakat dan pihak-pihak yang berkepentingan, yang diperlukan untuk memperoleh data dan informasi secara akurat di lapangan. Data yang digunakan dalam penelitian ini bersumber dari data sekunder dan data primer.

Adapun teknik-teknik pendukung metode ZOPP yang akan digunakan dalam penelitian ini adalah: (1) Teknik wawancara (interview). Responden yang diharapkan dapat diwawan- carai adalah: petani, pedagang, buruh tani, masyarakat, aparat, personal KUD/KUT, dan lainlain). (2) Kuesioner (angket). Sekitar 400 petani menjadi responden dalam studi ini. (3) Studi lapang (field research). Data diharapkan diperoleh dari: penduduk, petani, pedagang, buruh tani, pejabat, pengusaha, lembaga terkait (seperti KUD \& KUT). (4) Studi dokumentasi. Data diharapkan dapat diperoleh dari: BPS (terutama Jatim yang dijadikan lokasi studi kasus), Provinsi dalam angka, dan lain-lain. (5) Survey/observasi/pengamatan langsung. (6) Focus Group Discuss (FGD). (7) Community Group Interview

Teknik pengumpulan data poin (5) sampai (7) akan dilakukan di 11 kabupaten/kota yang mewakili di krovinsi Jawa Timur. Hal-hal yang dipertimbangkan dalam pemilihan lokasi tersebut adalah adanya kesesuaian data (kontribusi sektor pertanian pada PDRB, penduduk yang mayoritas sebagai petani dan hal-hal terkait lainnya) dengan topik yang akan menjadi fokus penelitian. Adapun kabupaten/kota yang dimaksud adalah: kabupaten Bangkalan, kabupaten Sampang, kabupaten Pamekasan, kabupaten Sumenep, kabupaten Lamongan, kabupaten Tuban, kabupaten Bojonegaro, kota Batu, kabupaten Malang, kabupaten Nganjuk dan kabupaten Ngawi.

\section{HASIL DAN PEMBAHASAN}

\section{Gambaran Kondisi Petani}

Pendidikan. Hasil survei pada petani di 11 kabupaten dan kota di Jawa Timur rata-rata berpendidikan antara SDTT (Sekolah Dasar Tidak Tamat) hingga SLTP. Anak-anak mereka ratarata juga bersekolah hanya sampai antara SD hingga SLTP, adapun yang berkesempatan mengenyam pendidikan hingga SMU hanya sebagian kecil saja (terutama anak laki-laki). Kondisi pendidikan yang rendah disebabkan karena adanya anggapan masyarakat bahwa pendidikan tinggi tidak terlalu berguna karena pada akhirnya mereka juga akan terjun ke dunia pertanian yang tidak membutuhkan "ilmu sekolahan". Walaupun anggapan tersebut sangat salah menurut para pengamat maupun ilmuwan manapun, tetapi realitas seperti itulah 
yang terjadi di seluruh lokasi survei di 11 kabupaten/kota di Jawa Timur. Seperti yang dituturkan oleh Ketua RT dusun Tretes kabupaten Malang (Pak To):

"Masyarakat daerah sini hampir semua lulusan SD, yang sekolah sampai SMP bisa dihitung (artinya tidak banyak), mungkin anaknya saja yang sekolah sampai SMA, yang kuliah ya ada, tetapi jarangjarang. Tapi di desa Tretes sini hampir tidak ada (yang berpendidikan sampai perguruan tinggi)."

Pernyataan Sulat (Petani di desa Kucur kabupaten Lamongan):

"Masyarakat Desa sini berfikir bahwa mengenyam pendidikan yang tinggi tetap saja tidak dapat apaapa, buktinya kalau sudah lulus ya sama saja akhirnya "ngarit" (istilah untuk memotong rumput). Ya memang tidak semuanya benar, tapi belum ada yang membuktikan, di sini yang dapat dicontoh itu belum ada."

Pendapatan. Hasil wawancara dengan \pm 400 petani, hampir semuanya mempunyai pekerjaan alternatif selain petani. Pendapatan yang diperoleh dari sektor pertanian rata-rata adalah di bawah Rp750.000,-/bulan. Tambahan pendapatan dari pekerjaan alternatif dipergunakan untuk mencukupi kebutuhan mereka seharihari. Jenis pekerjaan alternatif petani sangat bervariasi, sehingga besarnya pendapatan di luar sektor pertanian juga bervariasi.

Kebutuhan hidup masyarakat petani memang tergolong cukup sederhana dilihat dari pola makan dan gaya hidup. Tidak ada kehidupan yang terlihat mencolok. Bentuk rumah, misalnya, hampir seluruh gaya rumah sama, yang membedakan terkadang hanya luasnya saja. Perabotnya pun sangat sederhana, hampir semua memasak menggunakan kompor minyak dan tungku serta ada sebagian yang menggunakan kompor gas subsidi dari pemerintah. Makanan yang disantap setiap hari tidak menunjukkan kemewahan sama sekali.

Kehidupan petani memang sangat tergantung dari pendapatan mereka. Setiap harinya belum tentu memperoleh uang, karena waktu menerima pendapatan tidak pasti. Jika mereka hanya mengandalkan hasil pertanian, maka hasil yang didapatkan sangat berfluktuasi tergantung dari keberhasilan panen, cuaca, biaya produksi dan harga barang hasil produksi (apa- kah turun, normal atau naik). Jika kondisi buruk pendapatan petani bisa minus, artinya mengalami kerugian -uang yang digunakan untuk biaya produksi tidak kembali, bahkan terjerat hutang. Karena pada umumnya petani membeli benih pada Gapoktan dengan sistem hutang dan dibayarkan jika sudah panen. Tohir (Ketua Kelompok Tani) menuturkan:

"Saya selain mencangkul di sawah dan menggembala sapi, juga menjual pupuk, benih, serta pestisida. Sistemnya kerjasama dengan pabrik. Petani yang ikut kelompok tani saya, mengambil benih dan pupuk terlebih dahulu (hutang). Jika sudah saatnya panen, mereka yang tadinya telah mengambil benih dan pupuk akan membayar tanggungannya."

Kemudian penulis bertanya tentang sistem jaminan yang diberikan, Tohir menjawab:

"Caranya yaitu: pertama, saya harus melihat seberapa besar lahannya kemudian disesuaikan dengan kondisi cuaca dan prediksi keberhasilannya. Nah, dari situ nanti saya bisa menentukan berapa banyak nilai input pertanian yang bisa dipinjamkan. Demikian juga kalau ada orang yang mau meminjam uang, saya lihat dahulu semuanya, tapi tidak saya samakan seperti bisnis, kalau meminjamkan uang ikhlas, bagi saya uang akan kembali atau tidak sudah saya ikhlaskan dulu. Karena mencari saudara itu susah, tetapi kalau mencari musuh gampang".

Pada kutipan wawancara di atas memperlihatkan sistem pengadaan barang untuk kebutuhan produksi pertanian. Petani menggunakan sistem utang untuk membeli semua kebutuhan pertanian. Walaupun terkadang untuk benih tidak boleh dibayar kemudian (hutang) -semua tergantung kondisi pada saat transaksi berlangsung. Pertanyaannya adalah "apa yang terjadi jika gagal panen?" tentu saja petani tetap harus membayar hutangnya. Keadaan ini adalah salah satu keadaan yang dapat memiskinkan petani.

Dari empat kabupaten yang ada di Madura, kabupaten Sumenep dan Pamekasan didominasi oleh petani tembakau. Walaupun pendapatan kotor yang dihasilkan dari penjualan tembakau kepada tengkulak/pengepul sangat tinggi, namun keuntungan bersih yang mereka dapatkan sangat kecil. Sehingga petani tembakau pun harus mencari pekerjaan lain. Rata-rata jenis pekerjaan lainnya adalah sebagai nelayan. 
Lain halnya dengan petani di kabupaten Bangkalan dan kabupaten Sampang. Di dua kabupaten tersebut di dominasi oleh petani padi skala kecil. Hasil pertanian rata-rata untuk dikonsumsi sendiri dan dijual langsung ke kioskios kecil di sekitar rumah tempat tinggal mereka. Pekerjaan alternatif petani di kabupaten Sampang dan Bangkalan rata-rata adalah kerja "serabutan".

Contoh lain adalah pekerjaan alternatif petani di kabupaten Malang. Pendapatan lain yang diperoleh adalah pendapatan berternak lembu. Penghitungan pendapatan pada petani yang memilki 1 (satu) ekor lembu dapat menghasilkan rata-rata 10 (sepuluh) liter susu per hari. Petani desa Tretes rata-rata memiliki lembu 3-4 ekor dan harga susu Rp3000,- per liter. Hanya terdapat 2 (dua) orang yang memiliki lembu antara 10-12 ekor. Hasil perahan dijual ke Koperasi SAE dan diupah setiap 2 (dua) minggu sekali. Sehingga pendapatan rata-rata dari beternak lembu (dengan asumsi memiliki 3 ekor lembu) adalah Rp1.260.000,- per 2 (dua) minggu. Pendapatan tersebut masih dikurangi biaya untuk tenaga potong rumput. 1 kuintal rumput, jika menggunakan jasa ojek Rp15.000,sekali angkut. Jika potong rumput menggunakan tenaga manusia upah dibayarkan setiap tahun \pm Rp700.000,- per orang.

Sudarmo (45 tahun) sebagai contoh seorang petani yang memiliki 3 (tiga) ekor lembu tapi hanya 1 (satu) lembu yang berproduksi. Lembu Sudarmo setiap harinya dapat menghasilkan susu mencapai 12 liter per hari. Susu tersebut disetorkan ke koperasi SAE setiap hari dengan harga Rp3.000,- per liter dan baru mendapat upah dari koperasi SAE setiap 2 (dua) minggu sekali. Sehingga pendapatan Sudarmo yang bisa diprediksi setiap 2 (dua) minggu sekali kurang lebih adalah 12 liter $x$ Rp3000,- x 14 hari = Rp504.000,- pendapatan tersebut dikurangi biaya potong rumput jika menggunakan tenaga orang dan ditambah biaya ojek untuk pengangkutan rumput, dimana 1 kuintal rumput ongkos ojeknya Rp15.000,-. Dilihat dari konsistensi pendapatan, pendapatan dari pekerjaan alternatif lebih dapat diprediksi keuntungannya (lebih pasti) daripada pendapatan dari sektor pertanian.

\section{Penyebab Kemiskinan Petani dan Harapan Petani}

Hasil diskusi melalui pendekatan in depth interview dan focus group discuss kepada \pm 250 petani di 11 kabupaten dan kota yang menjadi lokasi penelitian menunjukkan bahwa harapan petani antara lain adalah: keberhasilan panen, kestabilan harga dan kelancaran input produksi. Asumsi dari ketiga keadaan tersebut adalah minimalisasi kerugian. Berbagai macam kendala dihadapi petani dalam rangka mewujudkan harapan mereka. Kendala-kendala tersebut yang pada akhirnya dapat menjadi penyebab kemiskinan petani.

Secara umum, penyebab kemiskinan di Indonesia adalah malapraktik pembangunan akibat formulasi kebijakan ekonomi (sosial dan politik) yang salah. Kebijakan-kebijakan ekonomi yang diproduksi oleh pemerintah cenderung mendahulukan kepentingan pemilik modal dan sektor industri/jasa ketimbang pelaku ekonomi kecil dan sektor pertanian (Oktavianti, 2007). Hasil analisis penelitian ini menunjukkan bahwa penyebab kemiskinan petani dilatarbelakangi oleh banyak hal, antara lain: kemampuan investasi petani yang rendah, ketergantungan petani, ketergantungan dana, dan tidak terpenuhinya kebutuhan pokok rumah tangga petani.

\section{Kemampuan Investasi yang Rendah}

Timbulnya masalah rendahnya kemampuan petani dalam berinvestasi disebabkan oleh beberapa masalah, antara lain: penguasaan teknologi pertanian yang terbatas, pengetahuan dan skill pertanian yang rendah, imperfect information, dan akses faktor produksi pertanian yang rendah. Hasil survei menunjukkan bahwa proses produksi pertanian sangat mengandalkan kondisi cuaca, luas lahan yang dimiliki dan ketergantungan terhadap pupuk-pupuk kimia serta berbagaimacam pertisida dan fungisida untuk memberantas hama. Penggunaan pupuk dan pertisida pun dilakukan dengan cara "coba-coba" tanpa melalui proses riset laboratorium atau semacamnya. Jika cuaca tidak mendukung, maka banyak petani-petani sayur, buah, padi, jagung, bunga, dan tembakau- yang mengalami gagal panen. Pertanyaannya adalah, 
"bagaimana jika cuaca sepanjang tahun tidak mendukung?", apakah petani yang harus menanggung kerugian terus menerus atas keadaan tersebut.

Rendahnya pendidikan yang disandang oleh petani mempunyai kontribusi besar dalam masalah penguasaan pengetahuan, skill dan teknologi. Pendidikan petani antara SDTT (Sekolah Dasar Tidak Tamat) sampai SLTP, dan rata-rata mengenyam pendidikan SD. Rendahnya tingkat pendidikan mereka disebabkan oleh pandangan masyarakat yang tidak menempatkan pendidikan sebagai prioritas utama. Oleh karena kesadaran berpendidikan yang rendah, akses untuk menguasai teknologi dan skill menjadi sangat sulit.

Selain itu, informasi berkaitan dengan harga, pasar, teknologi, iklim, dan sebagainyanya, sangat sedikit sekali dimiliki oleh petani. Lemahnya jaringan informasi yang dimiliki petani terhadap tanaman apa yang sedang diproduksi di daerah lain, juga menyebabkan kerugian pada petani. Hal tersebut dikarenakan barang pertanian akan melimpah jika sayur yang mereka tanam sama. Sehingga harga barang pertanian akan turun. Kondisi imperfect information semacam ini juga menimbulkan rendahnya akses input produksi kepada petani yang pada akhirnya akan menyebabkan rendahnya kemampuan investasi petani.

Termasuk juga, kepemilikan lahan petani rata-rata kurang dari 1 ha dan hanya sebagian kecil saja yang memiliki lahan 1-1,75 ha bahkan ada beberapa petani yang tidak mempunyai lahan sendiri dan memutuskan untuk menyewa atau memanfaatkan lahan dari Perhutani dengan sistem penanaman tumpang sari. Sempitnya lahan yang dimiliki oleh petani menyebabkan produksi pertanian hanya sedikit, bahkan sering kali tidak bisa memenuhi kebutuhan yang diinginkan oleh tengkulak/pengepul. Jika terjadi demikian, maka petani tersebut tidak bisa memborongkan tanamannya dan harus menjualnya sendiri ke pasar atau menunggu barang kali ada pembeli kecil yang menginginkan tanamannya. Apabila biaya akomodasi untuk panen dan transportasi dirasa memberatkan dan tidak seimbang dengan harga penjualan, maka petani akan mengambil tindakan un- tuk tidak menjual tanamannya dan akan memanfaatkannya untuk pakan ternak mereka. Nasib yang lebih buruk menimpa petani yang tidak memiliki lahan pribadi. Mereka yang tidak mempunyai lahan biasanya menjadi buruh tani atau adapula yang menggarap lahan milik Perhutani. Para petani memiliki kesepakatan dengan Perhutani untuk menanam pohon yang ditentukan oleh Perhutani dan sebagai imbalannya Perhutani memberi 20 (dua puluh) kayu dari 100 (seratus) kayu yang dipanen dan memperbolehkan para petani untuk memanfaatkan yang ditanami pohon tersebut dengan sistem tumpang sari. Sehingga bagi petani yang hanya mengandalkan lahan tersebut tidak akan memperoleh hasil yang banyak, karena tugas mereka tidak dapat memanfaatkan lahan yang ada dengan maksimal. Adapun petani yang juga tidak mempunyai lahan sendiri atau lahan sewa dan juga lahan pinjaman dari Perhutani, maka akan menjadi buruh tani, yang penghasilannya rata-rata Rp7.000,- sampai Rp12.000,- setiap setengah hari bekerja (antara jam 08.00-12.00).

\section{Ketergantungan Petani}

Masalah-masalah yang menjadi penyebab ketergantungan petani antara lain: jiwa entrepreneur yang rendah, ketersediaan modal yang tidak memadai, moral hazard, serta lemahnya dukungan kelembagaan pertanian. Memang untuk membangun pertanian dibutuhkan mobilisasi rakyat perdesaan. Mobilisasi rakyat pedesaan sendiri menuntut adanya struktur ekonomi yang mendukung, misalnya prasarana pertanian, investasi dan sarana/prasarana transportasi (Gulo, dkk; 2005). Sampai penelitian ini ditulis, pemerintah telah menyediakan sarana kelembagaan dengan membentuk kelompok-kelompok tani di masing-masing desa, tetapi pada kenyataanya banyak kelompok tani yang berfungsi, bahkan miskin keanggotaan. Jarang ditemui kelompok tani yang aktif. Fungsi-fungsi koperasi maupun kewirausahaan tidak muncul dalam kelompok-kelompok tani yang ada. Kegiatan umum kelompok tani, ratarata adalah arisan saja. Hal ini terjadi disebabkan oleh adanya moral hazard dan lemahnya dukungan kelembagaan pertanian. Buruknya sis- 
tem manajemen organisasi kelompok tani juga memperparah kondisi kelompok tani.

\section{Ketergantungan Dana}

Ketergantungan dana dialami baik oleh petani maupun oleh dinas pertanian sebagai pendorong kemajuan pertanian dan kesejaheraan petani. Kondisi petani yang miskin modal dan rendahnya skill enterpreneur membuat keadaan petani pasif dan hanya menggantungkan pinjaman modal dari KUD atau lembaga keuangan bank dan non-bank.

Keterbatasan modal yang dimiliki petani berdampak pada kemiskinan yang diderita petani. Modal sangat diperlukan ketika seseorang bergerak di bidang pertanian. Mereka memerlukan modal untuk berbagai kebutuhan proses bertani, mulai dari biaya tenaga kerja, kebutuhan pupuk dan pestisida (ladang 0,25 ha membutuhkan biaya 1 juta untuk sekali tanam), kebutuhan benih, biaya transportasi, dan lainlain. Sehingga pada masa awal tanam sampai dengan masa panen, petani membutuhkan modal yang cukup besar -tetapi mereka tidak bisa memprediksi hasil yang akan mereka peroleh. Oleh karena itu, petani akan memutuskan untuk meminjam uang ke bank jika mereka mampu atau berhutang kepada ketua kelompok tani atau kepada orang yang dapat mereka pinjami. Sistem kredit bank memang dirasa sangat memberatkan petani, karena bunga yang cukup tinggi, yakni mencapai 2 persen lebih. Sedangkan sistem pinjaman kepada ketua KUT dibangun dengan dasar kepercayaan dan asset yang dimiliki petani peminjam.

Kurangnya modal membuat petani tidak bisa melakukan proses produksi pertanian. Jika para petani tersebut memaksa untuk tetap berproduksi maka mereka harus mengupayakan pengadaan biaya produksi. Oleh karena itu, kebanyakan petani menempuhnya dengan jalan utang. Utang dapat mereka ajukan ke bank, kepada ketua KUT atau kepada individu yang dianggap mampu. Tentu saja sistem peminjaman di masing-masing tempat tersebut berbeda. Pertama, jika petani meminjam kepada bank maka risiko yang ditanggung adalah tingginya bunga bank. Sehingga ketika mereka mengalami gagal panen/kerugian maka utang mereka kepada bank akan menumpuk. Demikian halnya dengan peminjaman kepada koperasi, bedanya hanya pada segi besaran bunga. Kedua, jika para petani meminjam kepada Ketua KUT sistemnya akan berbeda. Ketua KUT lebih mengandalkan pada kepercayaan (trust), tetapi tetap memperhatikan prediksi keberhasilan petani peminjam. Sehingga, dalam sistem kedua ini lebih lunak dan lebih nampak modal sosialnya. Tetapi, jika petani mengalami gagal panen/kerugian, maka yang lebih terkena dampaknya adalah petani peminjam. Dengan demikian kemiskinan akan kembali menimpa petani kecil. Kemiskinan menyebabkan masyarakat desa (petani) rela mengorbankan apa saja demi keselamatan hidup (Scott dalam Sahdan, 2007)

Sedangkan ketergantungan dana dinas pertanian juga sangat terhadap alokasi anggaran dalam menjalankan fungsinya sebagai pihak yang bertanggungjawab atas kemajuan sektor pertanian dan kesejahteraan petani akan berimbas pada kinerja yang kurang maksimal. Sehingga output program yang dihasilkan tidak maksimal. Hal ini akan sangat berpengaruh pada nasib petani sebagai obyek yang sangat terkait dengan dinas pertanian.

\section{Tidak Terpenuhinya Kebutuhan Pokok}

Jika petani ditanya mengenai pemenuhan kebutuhan pokok sehari-hari, dengan tegas mereka menjawab "cukup". Akan tetapi yang perlu diteliti adalah apakah 'cukup' berarti tidak hutang atau berarti ada sumber pendapatan lain untuk memenuhi kebutuhan pokok tersebut. Temuan di lapang menunjukkan bahwa petani dapat memenuhi semua kebutuhan pokoknya adalah dari sumber pendapatan lain (pendapatan alternatif). Hal ini disebabkan karena sektor pertanian bersifat uncertainty. Kondisi serba tidak pasti -baik harga, pasar, panen, dan sebagainya- sehingga kondisi tersebut menyebabkan pendapatan petani dari sektor pertanian sangat rendah.

\section{Matrik Masalah}

Keterkaitan masalah yang sudah teridentifikasi melalui analisis masalah, dapat diketahui lebih mendalam menggunakan matriks masalah. 
Tabel 1. Matrik Masalah Kemiskinan Petani

\begin{tabular}{|c|c|c|c|c|c|c|c|c|}
\hline \multirow{2}{*}{\multicolumn{2}{|c|}{ Masalah akibat }} & \multicolumn{6}{|c|}{ Institusi } & \multirow[t]{3}{*}{ Jml } \\
\hline & & \multicolumn{3}{|c|}{$\frac{\text { KUT/Gapoktan }}{\text { Masalah }}$} & \multicolumn{2}{|c|}{$\frac{\text { Dinas Pertanian }}{\text { Masalah }}$} & \multirow{2}{*}{$\begin{array}{c}\text { Perangkat Desa } \\
\text { Masalah } \\
6 \\
\end{array}$} & \\
\hline Institusi & Masalah & 1 & 2 & 3 & 4 & 5 & & \\
\hline \multirow{11}{*}{$\begin{array}{l}\text { KUT/ } \\
\text { Gapoktan }\end{array}$} & - Akses input terbatas & & $x$ & $x$ & & & & 2 \\
\hline & - Imperfect information & $x$ & $X$ & $x$ & & $x$ & & 4 \\
\hline & $\begin{array}{l}\text { Ketersediaan } \\
\text { teknologi terbatas }\end{array}$ & & & $x$ & & $x$ & & 2 \\
\hline & $\begin{array}{l}\text { - Pengetahuan dan skill } \\
\text { rendah }\end{array}$ & $x$ & $x$ & $x$ & & $x$ & & 4 \\
\hline & - Keterbatasan modal & $X$ & & $x$ & & & $x$ & 3 \\
\hline & - Moral hazard & $x$ & & & & & & 1 \\
\hline & - Ketidakstabilan harga & $x$ & $X$ & & & & & 2 \\
\hline & - Uncertainty & $x$ & $x$ & $x$ & & $x$ & & 4 \\
\hline & - Price taker & $x$ & $x$ & & & & & 2 \\
\hline & - High transaction cost & $x$ & & $x$ & & $x$ & & 3 \\
\hline & $\begin{array}{l}\text { Manajemen } \\
\text { organisasi buruk }\end{array}$ & & & $X$ & $x$ & & $x$ & 3 \\
\hline \multirow{2}{*}{$\begin{array}{l}\text { Dinas } \\
\text { pertanian }\end{array}$} & - SDM terbatas & & & & $x$ & $x$ & & 2 \\
\hline & - Dana terbatas & $x$ & & & $x$ & & $X$ & 2 \\
\hline \multirow[t]{2}{*}{$\begin{array}{l}\text { Perangkat } \\
\text { Desa }\end{array}$} & $\begin{array}{l}\text { - Bukan penentu } \\
\text { kebijakan }\end{array}$ & $x$ & & & $X$ & & $x$ & 2 \\
\hline & Jumlah & 10 & 6 & 8 & 4 & 6 & 4 & \\
\hline
\end{tabular}

Sumber: data primer 2010, diolah peneliti

Keterangan: 1.Kemiskinan, 2.Ketergantungan, 3.Kemampuan investasi rendah, 4.Fungsi tidak maksimal, 5.Kurang memahami masalah petani, 6.Ketergantungan dana.

Suatu masalah dapat mempengaruhi dan/atau dipengaruhi oleh masalah intinya, yaitu kemiskinan petani. Matrik masalah yang ditunjukkan oleh Tabel 1 dapat digunakan untuk memperkirakan unit/instansi yang terlibat dalam masalah kemiskinan petani.Sehingga dapat dilakukan koordinasi secara intensif agar masalah kemiskinan petani dapat diatasi dengan baik. Selain itu, dapat pula ditentukan prioritas penanganan untuk program yang memiliki masalah paling banyak.

Tabel 1 memberikan informasi bahwa rendahnya pendapatan petani dari sektor pertanian mempunyai nilai terbesar yaitu 10 . Hal ini berarti bahwa permasalahan yang menjadi penyebab utama kemiskinan petani adalah rendahnya pendapatan petani dari sektor pertanian. Jika kita telaah kembali pada penyebab kemiskinan pada petani,maka kondisi rendahnya pendapatan petani dipicu oleh kebijakan pemerintah yang belum propetani. Sehingga menyebabkan lebih banyak uncertainty. Semakin besar uncertainty semakin besar pula resiko yang dihadapi petani. Kondisi spekulatif yang tidak menguntungkan petani akan terus menjadi keadaan yang dapat menghambat kemajuan sektor pertanian dan kesejahteraan petani.

Sedangkan unit terkait yang harus menjadi prioritas untuk diperhatikan adalah kolompok tani atau Gapoktan (Gabungan Kelompok Tani) dan/atau KUT (Kelompok Usaha Tani). Unit kelompok tani mempunyai nilai sebesar 4 untuk 'permasalahan penyebab' yaitu pengetahuan dan skill yang rendah serta ketidakstabilan harga. Nilai tersebut merupakan nilai terbesar, yang berarti bahwa program dan kebijakan yang dibuat nantinya harus dapat memprioritaskan penyelesaian masalah pengetahuan dan skill petani serta ketidakstabilan harga. 


\section{Matrik Analisis Partisipasi}

Identifikasi permasahan yang ditunjukkan oleh Tabel 1 dapat diperoleh peneliti melalui proses diskusi dalam bentuk pendekatan in depth interview dan focus group discuss. Hasil analisis partisipasi dari kedua proses pendekatan tersebut dapat dilihat pada Tabel 2. Tabel tersebut menginformasikan berbagai macam kepentingan/harapan, kekhawatiran, konflik, serta kelemahan dari berbagai instansi/unit yang terlibat dalam penyelesaian masalah kemiskinan petani.

Salah satu temuan yang menarik adalah adalah semangat gotong royong memang sangat melekat dan menjadi budaya masyarakat desa. Akan tetapi semangat gotong royong hanya mencakup skop yang sempit dan sangat dibatasi oleh wilayah di mana mereka tinggal. Kerjasama dalam arti luas, yakni dalam lingkup petani, baik antardesa atau antarwilayah dirasa sangat kurang. Hal ini dapat dilihat dari kebersamaan waktu penanaman padi. Menurut salah seorang petani yang cukup berpengalaman di Desa Kedungmiri-Karangjati Kabupaten Ngawi, menanam padi dalam waktu yang bersamaan sangatlah menguntungkan, mengingat kerugian yang lebih banyak ditanggung jika menanam padi secara individual. Hama -seperti tikus- akan sangat mudah menyerang dan menyebabkan gagal panen apabila petani mena-

Tabel 2. Matrik Analisis Partisipasi

\begin{tabular}{|c|c|c|c|c|c|c|}
\hline No & Kelompok & Kepentingan & Kekhawatiran & Konflik & Potensi & Kelemahan \\
\hline 1 & $\begin{array}{l}\text { Kelompok } \\
\text { Tani dan } \\
\text { atau } \\
\text { Gapoktan }\end{array}$ & $\begin{array}{l}\text { Keberhasilan } \\
\text { panen, } \\
\text { Kestabilan } \\
\text { harga, } \\
\text { Kelancaran } \\
\text { input } \\
\text { pertanian. }\end{array}$ & $\begin{array}{l}\text { Gagal panen, } \\
\text { Harga anjlok, } \\
\text { Input pertanian } \\
\text { tersendat, } \\
\text { Price taker, } \\
\text { High transaction } \\
\text { cost. }\end{array}$ & $\begin{array}{l}\text { Konflik } \\
\text { internal, } \\
\text { Konflik } \\
\text { eksternal, } \\
\text { Moral } \\
\text { hazard. }\end{array}$ & $\begin{array}{l}\text { Kebersamaan, } \\
\text { Gotong- } \\
\text { royong, } \\
\text { Trust. }\end{array}$ & $\begin{array}{l}\text { Manajemen } \\
\text { organisasi } \\
\text { buruk, } \\
\text { Uncertainty, } \\
\text { Akses modal } \\
\text { rendah, } \\
\text { Skill rendah, } \\
\text { Imperfect } \\
\text { Information. }\end{array}$ \\
\hline 2 & $\begin{array}{l}\text { Pedagang } \\
\text { Input } \\
\text { Pertanian }\end{array}$ & $\begin{array}{l}\text { Keuntungan, } \\
\text { Distributor } \\
\text { penyedia input } \\
\text { pertanian. }\end{array}$ & Competition & & $\begin{array}{l}\text { Monopoli } \\
\text { Harga Input }\end{array}$ & \\
\hline 3 & Tengkulak & $\begin{array}{l}\text { Keuntungan, } \\
\text { Free rider, } \\
\text { Price maker. }\end{array}$ & $\begin{array}{l}\text { Rule, } \\
\text { Eksistensi } \\
\text { BULOG, } \\
\text { Koperasi, KUT, } \\
\text { dll. }\end{array}$ & Harga & $\begin{array}{l}\text { Penguasaan } \\
\text { pasar, } \\
\text { Spekulator. }\end{array}$ & \\
\hline 4 & $\begin{array}{l}\text { Perangkat } \\
\text { Desa }\end{array}$ & $\begin{array}{l}\text { Penyedia } \\
\text { lahan } \\
\text { pertanian (rent } \\
\text { seeker) }\end{array}$ & & $\begin{array}{l}\text { Penyewa } \\
\text { lahan, } \\
\text { Pembagian } \\
\text { lahan. }\end{array}$ & Property Right & $\begin{array}{l}\text { Ketergantungan } \\
\text { terhadap ADD } \\
\text { besar }\end{array}$ \\
\hline 5 & $\begin{array}{l}\text { Dinas } \\
\text { Pertanian }\end{array}$ & $\begin{array}{l}\text { Kesejahteraan } \\
\text { petani, } \\
\text { Menjalankan } \\
\text { fungsi } \\
\text { birokrasi. }\end{array}$ & $\begin{array}{l}\text { Kemiskinan } \\
\text { petani }\end{array}$ & & $\begin{array}{l}\text { Skill, } \\
\text { Policy maker. }\end{array}$ & $\begin{array}{l}\text { Penguasaan } \\
\text { teknologi } \\
\text { pertanian } \\
\text { terbatas, } \\
\text { Kurang } \\
\text { memahami } \\
\text { permasalahan } \\
\text { petani, } \\
\text { Hanya pelaksana } \\
\text { kebijakan. }\end{array}$ \\
\hline
\end{tabular}

Sumber: data primer 2010, diolah peneliti 
nam padi secara individual. Demikian halnya dengan sayur, tanpa adanya kerjasama yang baik, misal dengan membuat kesepakatan adanya pembagian penanaman sayur, maka hasil yang diperoleh akan bisa diperhitungkan dan tidak menyebabkan harga barang komoditi yang satu naik sedangkan harga barang komoditi yang lain mengalami penurunan tajam. Keberadaan KUT memang dirasa sangat menunjang, akan tetapi institusi petani tersebut tidak berfungsi secara maksimal. Hal ini disebabkan karena pengetahuan masyarakat petani akan profesionalitas organisasi masih sangat kurang, pola komunikasi yang masih tradisional dan pendidikan yang rendah.

Bentuk tindakan kolektif (collective action) petani dapat ditemui pada keputusan tindakan untuk memulai menanam padi, mencari alternatif sumber pendapatan lain (seperti: beternak sapi perah di Kabupaten Malang, memproduksi karpet dan tikar di Kabupaten Lamongan, menjadi nelayan di Kabupaten Pamekasan dan Sampang), memilih jenis sayuran yang akan ditanam (petani sayur), penggunaan pupuk dan pestisida, serta memilih untuk menjadi anggota kelompok tani atau tidak. Berikut penjelasan tentang berbagai bentuk collective action petani di 11 lokasi penelitian di mana tindakan kolektif yang dilakukan oleh petani merupakan gerakan yang tidak terencana akan tetapi dilakukan berdasarkan kesamaan nasib.

\section{Keputusan Alternatif Sumber Pendapatan Non Pertanian}

Sumber pendapatan alternatif di luar sektor pertanian seperti yang telah dijelaskan di atas merupakan sumber pendapatan yang dapat membantu petani untuk survive. Karena pendapatan dari hasil produksi pertanian bersifat uncertainty. Berdasarkan hasil pengamatan dan survei lapang, pekerjaan non pertanian yang menjadi tumpuan petani sangat bervariasi. Akan tetapi ada beberapa kabupaten yang memiliki kesamaan dalam skop intraregional.

Misal di Kabupaten Malang dan Kota Batu sebagian besar pekerjaan alternatif petani adalah peternak sapi perah dan sapi pedaging, peternak sapi pedaging Kabupaten Ngawi, nelayan di Kabupaten Sampang dan Kabupaten
Pamekasan, Pengrajin karpet dan tikar di Kabupaten Lamongan, buruh bangunan di Kabupaten Bangkalan dan Kabupaten Bojonegoro.

Berikut adalah contoh hasil beternak sapi perah di Dusun Tretes. Semua petani yang memiliki sapi perah, hasil produksi susunya dijual melalui koperasi SAE. Jumlah sapi perah yang mereka miliki berkisar antara 1 (satu) sampai 12 (dua belas) ekor, namun rata-rata petani Dusun Tretes memiliki 2 (dua) sampai 3 (tiga) ekor lembu. Berikut kutipan dari pernyataan Umar ketika penulis melakukan wawancara:

".....di rumah ada lembu yang bisa membantu mencukupi penghasilan".

Sudarmo (45 tahun), seorang petani yang tidak memiliki lahan sendiri tetapi memiliki 3 (tiga) ekor lembu, mengatakan:

"Sapi saya ada 3 (tiga), tapi yang bisa diambil susunya hanya 1 (satu). Petani di sini kalau tidak ada ternak susah mbak. Lembu itu hanya sebagai sampingan tapi menjadi penghasilan utama. Itu saja terkadang kalau anak saya sendiri ingin susu, saya rasanya sayang (kalau susu buat konsumsi sendiri)."

Keputusan untuk memiliki sapi perah disebabkan karena adanya keterbukaan informasi alasan kepemilikan sapi perah. Seorang petani memutuskan untuk memelihara sapi perah karena adanya informasi dari petani lain bahwa dengan memelihara sapi perah maka akan dapat meningkatkan penghasilan. Informasi bahwa memelihara sapi perah akan dapat menambah penghasilan secara signifikan bisa didapat oleh petani pencari informasi kepada seluruh petani yang telah memelihara sapi perah dengan manfaatkan susunya untuk dijual. Setelah mendapatkan berbagai macam informasi yang positif, maka ia akan memutuskan untuk membeli sapi perah. Permasahan kedua adalah pencarian informasi tentang harga sapi perah dan pemilihan kualitas sapi perah yang baik. Informasi aktivitas kedua ini bisa didapatkan dari seluruh petani yang telah memiliki sapi perah. Pada akhirnya petani yang telah mendapatkan banyak informasi membeli sapi perah sesuai dengan informasi yang dapat sebelumnya.

Faktor ketidakpastian (uncertainty) harga 
menjadi salah satu penyebab kemiskinan petani. Kerugian yang harus mereka tanggung merembet pada hutang yang terus bertambah seiring dengan rendahnya harga jual komoditas pertanian dan kegagalan panen. Hal inilah yang menyebabkan petani mengambil keputusan untuk beternak sapi perah. Sebagai contoh, petani Dusun Tretes mendapat kepercayaan dari koperasi SAE untuk terus membeli semua susu perahan petani Dusun Tretes. Harga penjualan susu dari petani kepada koperasi SAE mencapai Rp3.000,- per liter. Seekor lembu mampu menghasilkan 10 (sepuluh) liter lembu dalam sehari. Sehingga pendapatan yang dapat diperoleh dalam jangka waktu 2 (dua) minggu adalah: Rp420.000,- per 2 (dua) minggu. Pendapatan inilah yang bisa diharapkan kepastiannya oleh petani. Dengan demikian beternak lembu merupakan faktor yang mempengaruhi peningkatan kesejahteraan petani Dusun Tretes. Sebuah harapan petani terungkap ketika dilakukan FGD.

"Ya, seandainya ada kredit lembu dari pemerintah, petani sangat senang. Kita ini tidak perlu diberi bantuan yang gratis-gratis. Pokoknya yang lebih penting itu bisa memotivasi".

Lalu ketua RT (Pak To) menimpali:

"Iya lebih baik itu dikasih bantuan kredit, seperti kredit lembu. Daripada dikasih bantuan BLT, karena akan menyebabkan orang iri. Karena apa..., lembu itu sampingan tetapi bisa menjadi penghasilan utama. Kalau BLT menyebabkan orang itu tergantung, belum lagi nanti ada banyak orang yang iri, kalau tidak dapat (BLT)".

Dari pendapat tersebut dapat disimpulkan bahwa petani sangat mengharapkan adanya bantuan pemerintah tentang pengadaan kredit sapi perah. Program penanggulangan kemiskinan berupa Bantuan Langsung Tunai (BLT) yang juga telah didistribusikan, menuai tanggapan yang kurang positif. Artinya, masyarakat menilai bahwa BLT hanya bersifat sementara dan menyebabkan ketergantungan serta masalah sosial (seperti: iri hati). Dampak sosial yang ditimbulkan oleh adanya BLT dapat mempengaruhi secara negatif modal sosial petani.
Keputusan Memulai Menanam Padi dan Menentukan Jenis Produksi Pertanian

Bentuk tindakan kolektif (collective action) dapat dijumpai pada saat petani memulai menanam padi di beberapa lokasi penelitian, seperti di kabupaten: Bojonegoro, Malang dan Nganjuk. Penanaman padi mereka mulai bersama-sama dengan melihat musim. Mereka menanam padi 2-3x (dua sampai tiga kali) dalam setahun.

Penanaman padi dilakukan bersama-sama demi menghindari risiko gagal panen yang tinggi. Risiko gagalnya panen dapat diakibatkan karena adanya serangan hama wereng, burung, dan tikut sawah. Dalam banyak studi pertanian, diakui bahwa menanam padi secara bersama-sama serta penggunaan pupuk dan pestisida yang tepat secara kompak dapat menurunkan resiko terhadap serangan hama. Sehingga panen yang dihasilkan memuaskan. Meskipun demikian masih banyak petani yang memulai produksi padi secara individu.

\section{Dampak Tindakan Kolektif (Collective Ac- tion)}

Berbagai macam bentuk tindakan kolektif (collective action) petani akan memiliki pengaruh terhadap individu dan masyarakat secara luas yang akan berdampak pada tindakan individu itu sendiri. Jika masing-masing individu pada akhirnya memutuskan tindakan yang sama maka akan berpengaruh pula pada masyarakat. Gambar 1 ini menggambarkan hubungan antara tindakan kolektif (collective action) dengan tindakan individu dan masyarakat.

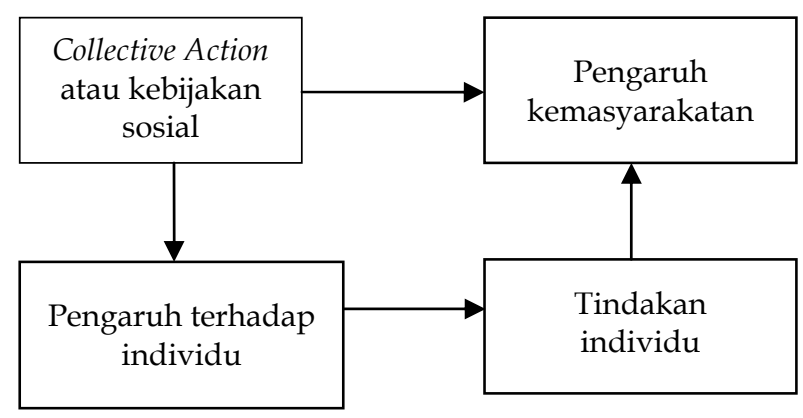

Sumber: Coleman, 1994

Gambar 1. Relasi Makro-ke-Mikro-ke-Makro dalam Pengaruh 


\section{Kebijakan Sosial}

Jika menurut petani tindakan yang bisa dilakukan untuk menstabilkan harga adalah dengan adanya informasi sempurna (perfect information) dari petani antarwilayah. Maka yang perlu mereka bangun adalah modal sosial dalam jaringan yang lebih luas, yaitu modal sosial petani yang tidak dibatasi oleh wilayah territorial. Modal sosial yang terbangun dengan baik akan memunculkan suatu gagasan atau pikiran yang cenderung sama antarpetani dan sama-sama mempunyai keinginan untuk memajukan kesejahteraan petani dan melahirkan tindakan bersama untuk membebaskan diri dari kemiskinan yang membelenggu petani dengan cara pembangunan interaksi sosial yang diilhami dari masing-masing individu petani. Tindakan seperti ini sudah sepatutnya menjadi perhatian pemerintah, di mana peneliti akan membasas pada poin selanjutnya tentang program dan kebijakan.

Berdasarkan alasan bahwa tindakan kolektif (collective action) ternyata memilki pengaruh yang besar bagi kesejahteraan petani meskipun tindakan-tindakan tersebut tidak terprogram dengan baik, maka peneliti akan menindaklanjuti potensi modal sosial yang tertranformasi dalam aksi kolektif tersebut ke dalam rancangan program-program yang lebih terarah. Dengan demikian petani bersama-sama dengan lembaga terkait beserta pemerintah dapat menyelesaikan berbagai macam permasalahan yang dihadapi petani. Sehingga petani dapat memperoleh peningkatan taraf hidup.

\section{Program-program Pengentasan Kemiskinan Petani Berbasis Tindakan Kolektif (Collec- tive Action)}

Kebijakan yang muncul dari adanya tindakan kolektif pada dasarnya secara alami telah diputuskan oleh sekelompok masyarakat. Instrumen kebijakan pembangunan lebih efektif mereduksi kemiskinan secara tajam dibanding dengan mengandalkan ketergantungan pada SDA yang melimpah tanpa adanya kebijakan yang berpihak pada rakyat miskin. Oleh karena itu melalui analisis secara bertahap, penelitian ini akan merumuskan kebijakan-kebijakan melalui pro- gram-program prioritas penanggulangan kemiskinan yang terpilih.

Tahap awal hasil analisis ZOPP yang tertuang dalam Matrik Pemilihan Program mencakup program-program yang disusun untuk mencapai kondisi yang diinginkan atau sesuai dengan tujuan yang telah ditentukan. Tujuan utama dari penelitian ini adalah tercapainya kesejahteraan petani. Di mana indikator kesejahteraan petani mencakup 3 (tiga) hal, yaitu: kemampuan berinvestasi yang tinggi, terpenuhinya kebutuhan pokok, serta tercapainya kemandirian petani. Dalam rangka mencapai tujuan tersebut dibutuhkan tahapan-tahapan agar petani sampai pada tujuan-akhir.

Prioritas penentuan program akan dilaksanakan sebagai langkah tindakan bertahap untuk mencapai tujuan utama, yaitu kesejahteraan petani. Hasil penyusunan Matrik Pemilihan Program dapat dilihat pada Tabel 3.

Hasil uji pertama, menunjukkan bahwa urutan proram dari nilai tertinggi hingga terendah adalah sebagai berikut: (1) Pembentukan/ pengaktivan KUT/Gapoktan (total nilai $=36$ ), (2) Penciptaan pasar bagi petani (total nilai = 34), (3) Pendampingan KUT/Gapoktan (total nilai =24), (4) Pengadaan lahan percontohan di masing-masing desa (total nilai $=23$ ), (5) Kerjasama KUT/Gapoktan dengan lembaga penelitian dan/atau universitas terkait (total nilai 18)

Dari hasil tersebut peneliti akan mengambil 4 (empat) program dengan nilai tertinggi dan selanjutnya dilakukan pegujian yang kedua untuk lebih menegaskan program mana yang akan lebih diprioritaskan sebagai program utama dan harus segera diwujudkan berdasarkan kriteria: dampak ekonomi, dampak sosial, kebutuhan sarana serta jangka waktu tercapainya dampak. Proses ini dilakukan menggunakan alat analisis Alternalif Pemilihan Pendekatan Program (Lihat Tabel 4).

Setelah melalui proses pegujian kedua, urutan prioritas program dari perolehan total nilai tertinggi hingga terendah adalah sebagai berikut: pertama, penciptaan pasar bagi petani (total nilai $=31$ ); kedua, pembentukan/pengaktifan KUT/Gapoktan (total nilai = 30); ketiga, pendampingan KUT/Gapoktan (total nilai = 
Tabel 3. Matrik Pemilihan Program

\begin{tabular}{|c|c|c|c|c|c|}
\hline Kriteria & $\begin{array}{c}\text { Penciptaan } \\
\text { pasar bagi } \\
\text { petani } \\
\\
\text { (Program } \\
\text { 1) }\end{array}$ & $\begin{array}{c}\text { Pembentukan } \\
\text { /pengaktifan } \\
\text { (KUT)/ } \\
\text { Gapoktan } \\
\text { (Program 2) }\end{array}$ & $\begin{array}{c}\text { Pendampingan } \\
\text { KUT/ } \\
\text { Gapoktan } \\
\text { (Program 3) }\end{array}$ & $\begin{array}{l}\text { Pengadaan } \\
\text { lahan } \\
\text { percontohan } \\
\text { di tiap Desa } \\
\text { (Program 4) }\end{array}$ & $\begin{array}{c}\text { Kerjasama KUT/ } \\
\text { Gapoktan dgn } \\
\text { Lembaga } \\
\text { Penelitian \& } \\
\text { /atau Universitas } \\
\text { terkait } \\
\text { (Program 5) }\end{array}$ \\
\hline $\begin{array}{l}\text { 1. Prinsip } \\
\text { pembangunan: } \\
\text { - pemerataan } \\
\text { - peningkatan }\end{array}$ & 5 & 4 & 1 & 2 & 3 \\
\hline 2. Kebijakan Pemerintah & 2 & 5 & 4 & 3 & 1 \\
\hline 3. Efektifitas biaya & 1 & 5 & 4 & 2 & 3 \\
\hline 4. Kesinambungan & 5 & 1 & 4 & 2 & 3 \\
\hline $\begin{array}{l}\text { 5. Pemanfaatan } \\
\text { maksimal }\end{array}$ & 2 & 5 & 1 & 4 & 3 \\
\hline $\begin{array}{l}\text { 6. Keterbatasan Sumber } \\
\text { Daya }\end{array}$ & 5 & 3 & 1 & 4 & 2 \\
\hline 7. Aksesibilitas & 4 & 5 & 3 & 2 & 1 \\
\hline $\begin{array}{l}\text { 8. Peningkatan } \\
\text { pendapatan }\end{array}$ & 5 & 4 & 3 & 2 & 1 \\
\hline 9. Replikabilitas & 5 & 4 & 3 & 2 & 1 \\
\hline Total nilai & 34 & 36 & 24 & 23 & 18 \\
\hline
\end{tabular}

Sumber: data primer 2010, diolah peneliti

26); dan keempat, pengadaan lahan percontohan di masing-masing desa (total nilai $=13$ )

\section{Bentuk Kebijakan Pemerintah kepada Petani}

Hasil analisis program telah diketahui 4 (empat) program utama yang harus menjadi prioritas dalam rangka mensejahterakan petani. Pada Tabel 5 dalam Lampiran diperlihatkan kerangka kerja logis (logical framework) dalam rangka menyusun kebijakan-kebijakan apa saja yang harus dilakukan.

Kerangka kerja logis tersebut menggambarkan ringkasan rancangan program pengentasan kemiskinan petani menggunakan matrik dengan memperhatikan asumsi-asumsi, sumber permbuktian, indikator untuk setiap tingkatan tujuan yang ingin dicapai. Kerangka kerja logis dimaksudkan untuk melakukan penilaian terhadap setiap kebijakan yang digambarkan seca-

Tabel 4. Matrik Pemilihan Pendekatan Program

\begin{tabular}{|c|c|c|c|c|c|c|c|c|c|}
\hline \multirow{2}{*}{ Kriteria } & \multicolumn{4}{|c|}{ Penilaian tegas } & \multirow{2}{*}{$\begin{array}{l}\text { Bobot } \\
\text { (skor) }\end{array}$} & \multicolumn{4}{|c|}{$\begin{array}{c}\text { Penilaian tegas dengan } \\
\text { pembobotan }\end{array}$} \\
\hline & $\begin{array}{c}\text { Prog. } \\
1\end{array}$ & $\begin{array}{c}\text { Prog. } \\
2\end{array}$ & $\begin{array}{c}\text { Prog. } \\
3\end{array}$ & $\begin{array}{c}\text { Prog. } \\
4\end{array}$ & & $\begin{array}{c}\text { Prog. } \\
1\end{array}$ & $\begin{array}{c}\text { Prog. } \\
2\end{array}$ & $\begin{array}{c}\text { Prog. } \\
3\end{array}$ & $\begin{array}{c}\text { Prog } \\
4\end{array}$ \\
\hline 1. Dampak Sosial & 1 & 4 & 3 & 2 & 3 & 3 & 12 & 9 & 6 \\
\hline 2. Dampak Ekonomi & 4 & 3 & 2 & 1 & 4 & 16 & 12 & 8 & 4 \\
\hline 3. Kebutuhan sarana & 4 & 2 & 3 & 1 & 2 & 8 & 4 & 6 & 2 \\
\hline $\begin{array}{l}\text { 4. Jangka waktu tercapainya } \\
\text { dampak }\end{array}$ & 4 & 2 & 3 & 1 & 1 & 4 & 2 & 3 & 1 \\
\hline Jumlah nilai & 13 & 11 & 11 & 5 & & 31 & 30 & 26 & 13 \\
\hline
\end{tabular}

Sumber: data primer 2010, diolah peneliti 
ra logis berdasarkan kondisi yang ada saat ini, dikaitkan dengan kondisi yang diharapkan sebagai dampak yang dapat timbul dari pelaksanaan kebijakan di masa yang akan datang.

Berdasarkan program-program yang telah disusun dan dianalisis dalam sub bab sebelumnya, maka terdapat implementasi kebijakan untuk masing-masing program. Implementasi kebijakan tersebut antara lain: pertama, program penciptaan pasar bagi petani. Implementasi kebijakan dari program ini adalah adanya pembelian produk pertanian oleh pemerintah serta penciptaan skill tinggi bagi petani untuk menciptakan produk kualitas tinggi. Kedua, program pembentukan/pengaktifan KUT/Gapoktan. Implementasi program kedua mencakup 2 (dua) segmen, yaitu implementasi kebijakan oleh internal KUT/Gapoktan yang mencakup pelatihan kewirausahaan dan penginternalisasian fungsi koperasi. Adapun segmen berikutnya adalah implementasi kebijakan oleh pemerintah yang mencakup: penyuluhan pertanian disesuaikan dengan kondisi input pertanian masing-masing daerah, penyediaan sarana pembentukan/pengaktifan KUT/Gapoktan, penyediaan fasilitas penunjang teknologi pertanian, dan alokasi anggaran dana untuk pendorong aktifnya KUT/Gapoktan. Program ketiga adalah pendampingan KUT/Gapoktan yang dapat diimplementasikan dengan adanya pelatihan manajemen organisasi serta kemampuan menjalankan fungsi eksternal (networking). Program terakhir adalah pengadaan lahan percontohan di masing-masing desa. Kegiatan terakhir memberikan konsekuensi berupa tersedianya fasilitas lahan percontohan serta penyediaan sumber daya manusia (SDM) supervisor lahan percontohan di masing-masing desa (Tabel 5 dalam Lampiran).

\section{SIMPULAN}

Berdasarkan hasil analisis permasalahan pokok, terdapat 11 (sebelas) permasalahan mendasar yang menjadi penyebab kemiskinan petani. Hal tersebut antara lain: akses input pertanian terbatas, Imperfect information, ketersediaan teknologi terbatas, pengetahuan dan skill rendah, keterbatasan modal, moral hazard, ketidaksta- bilan harga, uncertainty, petani sebagai price taker, high transaction cost, management organisasi buruk, banyaknya tengkulak/pengepul sebagai price maker. Oleh karena itu berdasar analisis ZOPP, program-program prioritas yang berhasil disusun sebagai solusi bagi berbagai permasalahan tersebut antara lain: program penciptaan pasar bagi petani, program pembentukan/pengaktifan KUT/Gapoktan, program pendampingan KUT/Gapoktan, serta program pengadaan lahan percontohan di masingmasing desa.

Keempat program tersebut akan diimplementasikan dalam bentuk kebijakan-kebijakan. Program pertama dapat diimplementasikan melalui kebijakan pembelian produk pertanian oleh pemerintah serta penciptaan skill tinggi bagi petani untuk menciptakan produk kualitas tinggi. Program kedua yaitu program pembentukan/pengaktifan KUT/Gapoktan dimulai dengan diadakannya pelatihan kewirausahaan dan internalisasi fungsi koperasi pada lembaga KUT. Pada program kedua ini juga memerlukan peran dan dukungan dari pemerintah antara lain dalam bentuk: penyuluhan pertanian disesuaikan dengan kondisi input pertanian masing-masing daerah, penyediaan sarana pembentukan/pengaktifan KUT/Gapoktan, penyediaan fasilitas penunjang teknologi pertanian serta alokasi anggaran dana sebagai pendorong aktifnya KUT/Gapoktan. Program ketiga yaitu program pendampingan KUT/Gapoktan. Program ketiga dapat diterjemahkan ke dalam beberapa kegiatan seperti pelatihan manajemen organisasi, networking, serta penyediaan SDM pendamping di masing-masing desa sebagai konsekuensi pengadaan program. Program yang menjadi prioritas terakhir adalah program pengadaan lahan percontohan di masing-masing desa. Aplikasi dari program ini adalah tersedianya fasilitas lahan percontohan di masingmasing desa serta penyediaan SDM supervisor lahan percontohan di masing-masing desa.

\section{DAFTAR PUSTAKA}

Astuti dan Musiyam. 2009. Kemiskinan dan Perkembangan Wilayah di Kabupaten 
Boyolali. Forum Geografi, Vol.23, No.1. Universitas Muhammadiyah Surakarta.

BPS Indonesia. 2009. www.bps.go.id

BPS Jawa Timur. 2009. www.bps.jatim.go.id

Bratakusumah, D. Supriady. 2004. Perencanaan Pembangunan Daerah, Strategi Menggali Potensi dalam Mewujudkan Otonomi Daerah. Jakarta: Penerbit PT Gramedia Pustaka Utama.

Coleman, James S. 1994. Foundations of Social Theory. The Belknap Press of Harvard University Press. Terjemahan. Bandung: Penerbit Nusa Media.

Firman dan Herlina. 2003. Analisis Kemiskinan dan Ketimpangan Distribusi Pendapatan pada Peteernak Sapi Perah. Survey di Wilayah Kerja Koperasi Unit Desa Sinar Jaya Kabupaten Bandung. Jatinangor. Bandung.

Fukuyama, Francis. 1995. Trust: The Social Virtues and the Creation of Prosperity. New York: Free Press.

Gulo, dkk. 2005. Kebijakan dalam Upaya Menanggulangi Kemiskinan di Nias. Jurnal Studi Pembangunan. edisi Oktober, Vol.1, No.1. USU.

Hasibuan, Nurimansjah. 1993. Kemiskinan Struktural di Indonesia: Menembus Lapisan Bawah. Artikel bebas.
Kuncoro, AS. 2008. Kemiskinan: Kesenjangan Antarprovinsi. Project Officer untuk TAR GETMDGs (BAPENAS/UNDP). MDGs News edisi 01 Juli-September 2008.

Oktavianti, Henny. 2007. Menelaah Kemiskinan di Indonesia Perspektif Ekonomi Politik. Jurnal Ekonomi Terapan Indonesia, Vol.2, No. 2. Malang: BPFE Universitas Brawijaya.

Di Gregorio, M. and Meinzen-Dick, R. S. and (eds.) 2004. Collective Action and Property Rights for Sustainable Development. 2020 Focus 11. Washington, D.C.: International Food Policy Research Institute. http:// www.ifpri.org/2020/focus/focus11.htm

Sahdan, Gregorius. 2007. Menanggulangi Kemiskinan Kota. http://www.kemenegpdt.go. id/. diakses tanggal 5 April 2011.

Yustika, A. Erani. 2006. Ekonomi Kelembagaan: Definisi, Teori, dan Strategi. Malang: Bayu Media Publishing.

Yustika, A. Erani.. 2007. Perekonomian Indonesia: Satu Dekade Pascakrisis Ekonomi. Malang: Badan Penerbit Fakultas Ekonomi Universitas Brawijaya.

\section{LAMPIRAN}

Tabel 5. Matrik Kerangka Kerja Logis

\begin{tabular}{llll}
\hline \multicolumn{1}{c}{ Deskripsi } & \multicolumn{1}{c}{ Indikator obyektif } & Sumber pembuktian & \multicolumn{1}{c}{ Asumsi } \\
\hline Tujuan: & Pendapatan perkapita petani & $\bullet$ Hasil pemantauan di & $\bullet$ Good governance \\
Kesejahteraan Petani & meningkat & lapangan & $\bullet$ Social capital \\
& & Data statistik $(11$ & kab/kota yang diteliti) \\
& & & \\
\hline
\end{tabular}

Bersambung... 
Tabel 5.....

\begin{tabular}{|c|c|c|c|}
\hline Deskripsi & Indikator obyektif & Sumber pembuktian & Asumsi \\
\hline $\begin{array}{l}\text { Sasaran program: } \\
\text { Peningkatan pendapatan petani }\end{array}$ & $\begin{array}{l}\text { - Kelompok Tani (poktan) } \\
\text { berubah menjadi } \\
\text { Kelompok Usaha Tani } \\
\text { (KUT) } \\
\text { - Masing-masing KUT } \\
\text { mampu membeli alat-alat } \\
\text { produksi pertanian secara } \\
\text { mandiri setelah } 1 \text { tahun } \\
\text { mempergunakan alat }\end{array}$ & $\begin{array}{l}\text { - } \text { Poktan menjadi } \\
\text { KUT } \\
\text { - KUD } \\
\text { - Dinas pertanian } \\
\text { - Statistik ekonomi } \\
\text { dan keuangan BI } \\
\text { Jawa Timur }\end{array}$ & $\begin{array}{l}\text { - Pemerintah dan } \\
\text { petani sebagai } \\
\text { price maker } \\
\text { - Input produksi } \\
\text { lancar dan } \\
\text { terjangkau } \\
\text { - Pola hidup dan } \\
\text { daya beli petani } \\
\text { baik } \\
\end{array}$ \\
\hline $\begin{array}{l}\text { Hasil-hasil kerja: } \\
\text { - } \quad \text { Kebijakan pro petani } \\
\text { - } \quad \text { Dukungan kelembagaan } \\
\text { pertanian } \\
\text { - } \quad \text { Pengetahuan dan skill tinggi } \\
\text { di bidang pertanian } \\
\text { - } \quad \text { Kualitas bersaing produk } \\
\text { - } \quad \text { Pertanian baik } \\
\text { Produktivitas petani tinggi }\end{array}$ & $\begin{array}{ll}\text { - } & \text { Produksi pertanian } \\
\text { - } & \text { Peneningkat } \\
\text { - } & \text { produk pertanian membeli lokal } \\
\text { - } & \text { KUT lebih mandiri } \\
\text { - } & \text { Petani lebih trampil } \\
& \text { dalam mengatasi } \\
& \text { masalah pertanian }\end{array}$ & $\begin{array}{ll}\text { - } & \text { Dinas pertanian } \\
\text { - } & \text { Data statistik (11 } \\
\text { kab/kota yang } \\
\text { diteliti) } \\
\text { - } \quad \text { Pemantauan di } \\
\text { lapangan } \\
\text { - KUT }\end{array}$ & $\begin{array}{ll}\text { - } & \text { Rule berfungsi } \\
\text { - } & \text { Good governance } \\
& \text { terhadap produk } \\
& \text { pertanian lokal } \\
\text { meningkat } \\
\text { - } \\
\text { - } \text { Pestabilan harga } \\
\text { memerintah } \\
\text { produk pertanian } \\
\text { (terutama beras) }\end{array}$ \\
\hline
\end{tabular}

\section{Activities/Program:}

1. Penciptaan pasar bagi petani

- Pembelian produk pertanian lokal oleh pemerintah (terkecuali petani bunga)

2. Pembentukan/Pengaktifan KUT/Gapoktan

- Problem solver

- Pelatihan kewirausahaan

- Penyuluhan pertanian

- Menjalankan fungsi koperasi dalam KUT

3. Pendampingan

KUT/Gapoktan

- Pelatihan managemenorganisasi

- Pemantauan KUT

- (networking)

4. Pengadaan lahan percontohan di masingmasing desa

- Pusat percontohan awal (uji keberhasilan suatu produk)

- Pusat pelatihan dan percobaan riil pertanian
1. - Produksivitas petani \& pertanian meningkat

- Pendapatan petani meningkat

- Harga jual produk pertanian tinggi

2. - Terjalin kerjasama antar petani

- Mampu berwirausaha tani

- Penguasaanteknik produksi pertanian

- Bekerjasama dengan KUD setempat

3. - ManaJemen organisasi baik

- Konflik internal berkurang

- KUT berfungsi dengan baik

- Mereduksi moral hazard

- Tercapainya networking

4. - Adanya lahan percontohan di masing-masing desa

- Adanya kegiatan pelatihan percobaan riil terhadap suatu produk atau teknik pertanian
- Data Nilai Tukar - Collective action Petani (NTP) tinggi - Social capital

- Data produksi pertanian meningkat

- Data kemiskinan petani menurun

- Kualitas produk pertanian tinggi

- Laporan kerja Dinas Pertanian
- Dana mencukupi

- Good governance

- SDM memadai

- Kearifan lokal

\footnotetext{
Sumber: data primer 2010, diolah peneliti
} 